\title{
JOHN JAY: LAWYER IN A TIME OF TRANSITION, 1764-1775
}

\author{
Herbert Alan Johnson†
}

Unlike many of his associates in the leadership of the American Revolution, John Jay was already well established in law practice when the war broke out. Born into a financially secure and prominent mercantile family, he had been trained at King's College and in the law offices of Benjamin Kissam, a well known New York City attorney. Although young in years and experience, Jay had built up a large and remunerative practice before he began his public career in $1774 .{ }^{1}$ For this reason his life at the bar is a valuable point of departure for studying the legal profession in the last decade of the colonial period and for considering the role of the lawyer in colonial society and in the coming of the American Revolution.

\section{Legal Education}

Few periods in colonial New York were less auspicious for entering the legal profession than the years 1762 and 1763. In 1756 the attorneys of New York had agreed to restrict bar admissions by refusing to accept clerks for the next fourteen years. ${ }^{2}$ Aspiring lawyers were thus to be deprived of the substantial benefits of training in a law office within the province. With that path to the profession seemingly blocked when John Jay decided upon a law career in 1762, his family was forced to look elsewhere for his legal education. Peter Jay, John's father, consulted with relatives in England. ${ }^{3}$ He concluded that legal train-

$\dagger$ Editor, The Papers of John Marshall, Institute of Early American History and Culture, Williamsburg, Va.; Visiting Research Professor, Spring 1976, Southern Studies Program, University of South Carolina. A.B. 1955, M.A. 1961, Ph.D. 1965, Columbia University; LL.B. 1960, New York Law School. Member, New York and District of Columbia Bars.

${ }^{1}$ At the end of the American Revolution, Jay was minister to Spain and a member of the American commission appointed to negotiate a peace treaty. Before he returned to the United States, Jay intended to resume his law practice. Appointments as Secretary for Foreign Affairs and subsequently as first Chief Justice of the United States, however, prevented his returning to private life.

${ }^{2}$ Agreement of the Bar of New York City, dated Oct. 1756, in P. Hamlin, Legal Education in Colonial New York 160-61 (1939) [hereinafter cited as Hamlin].

${ }^{3}$ The relatives were Sir James Jay, John's brother who was then in London, and David Peloquin, of Bristol, a cousin of Peter Jay and his commercial correspondent. 
ing in the mother country would be an extremely expensive proposition. Mindful of the heady social atmosphere of the Inns of Court and their lack of pretension to serious legal education, Peter Jay wrote to David Peloquin, his Bristol cousin and commercial correspondent: "[T]hough I have hitherto no Reason to doubt of his behaving Well, as he is a youth remarkably sedate, and is well disposed, but nevertheless it's prudent to gard, as much as possible, against the danger of bad Company he would be exposed to in London ...."4 Peloquin, on the other hand, felt that because he lacked the proper contacts with members of the local bar, he probably would not be able to obtain a suitable clerkship placement for John in Bristol. ${ }^{5}$

Quite fortunately for the Jay family, and for John in particular, an unanticipated change in the policy of the New York bar resulted in the revocation of the 1756 agreement. $^{6}$ Within eleven days of the repeal of the suspension of clerkships, Peter Jay entered into preliminary arrangements with Benjamin Kissam, a New York City lawyer with an extensive practice, whom Peter Jay described as a "Gentleman eminent in the Profession."

Despite the alacrity with which the anxious father and son accepted the apprenticeship terms, the choice of John Jay's master proved to be wise. As a well-known and extremely busy attorney, Kissam at least equaled any other practitioner in the city of New York in the advantages he could provide a clerk studying the law. Little information concerning the man, however, has been preserved. We know that Kissam was about thirty-four years of age when Jay began his clerkship. Although Kissam was a member of a family prominent in Queens County legal circles, he centered his practice in New York City, where the highest courts of the province held their sessions. ${ }^{8}$ During the clerkship, Benjamin Kissam and John Jay developed a rare

${ }^{4}$ Letter from P. Jay to D. Peloquin, Apr. 14, 1763, in 3 Peter Jay Letterbook (Columbia University Libraries, Special Collections). See F. Monaghan, John Jay: Defender of Liberty Against Kings and Peoples 29 (1935).

${ }^{5}$ Letter from D. Peloquin to P. Jay, July 26; 1763 (private, collection of John Jay (a descendant), Williamstown, Mass.).

${ }^{6}$ Agreement of the Bar of New York City, concluded Jan. 5, 1764, in Hamlin, supra note 2 , at 163-64. note 4.

${ }^{7}$ Letter from P. Jay to D. Peloquin, May 15, 1764, in 3 P. Jay Letterbook, supra

${ }^{8}$ E. Kissam, The Kissam Family in AMerica from 1644 to 1825 , at 20-21 (1892). A number of attorneys practicing before the Queens County Court of Common Pleas were named Kissam. Daniel Kissam (1726-1782) and Daniel Kissam (1739-1812) were judges of that court. 
form of camaraderie, ${ }^{9}$ which must have rendered more bearable the grueling and tedious writing tasks assigned to all law clerks in the colonial period.

Jay entered his apprenticeship with a full appreciation of the difficult years that would intervene before his admission to the bar. When he had first announced his desire to enter the profession, his father had admonished him: "[A]s its [sic] your inclination to be of that Profession, I hope you'll closely attend to it with a firm resolution that no difficulties in prosecuting that Study shall discourage you from applying very close to it, and if possible, from taking delight in it."10

Twenty years before, young William Livingston had published two anonymous essays attacking the drudgery of his life as a law clerk and the inattention of the attorneys who accepted law clerks without training them in the law. The attendant publicity may have helped draw the bar into a reconsideration of its duties to the young men committed to its charge. ${ }^{11}$ Arduous copying duties were lightened by a growing reliance upon the use of printed litigation forms and papers prepared by scriveners. ${ }^{12}$ Nevertheless there still remained lengthy pleas in chancery, bulky briefs of counsel, wills and non-routine deeds and contracts, all of which required preparation in the handwriting of law clerks. John Jay and probably other senior law clerks were also expected to manage the business affairs of the law office by keeping accurate registers of costs and disbursements, preparing bills for services rendered, and drafting routine correspondence. ${ }^{13}$ The colonial law clerk performed all of the duties which today are assigned to a legal stenographer, as well as the functions of a managing clerk and a legal researcher.

${ }^{9}$ Specific incidents are recounted in H. Johnson, John Jay: Colonial Lawyer 70-71, June 1, 1965 (unpublished doctoral dissertation in Columbia University Library) [hereinafter cited as Colonial Lawyer].

${ }^{10}$ Letter from P. Jay to John Jay, Aug. 23, 1763, in 1 The Correspondence and Public Papers of John Jay 1763-1781, at 1 ( $\mathrm{H}$. Johnston ed. 1890) [hereinafter cited as CORRESPONDENCE].

11 T. Sedgwick, JR., A Memoir of the Life of William Livingston 48, 52, 56-57 (1832). When the shields of anonymity slipped, however, the outburst resulted in the transfer of Livingston's indenture to another attorney.

12 HAMLIN, supra note 2, at 41-43. An example of a pleading prepared by a scrivener can be seen in the case of Dugdale v. Carr (1775) (Mayor's Court Papers, Benjamin Salzer Collection, Columbia University Libraries, Special Collections). While the formal nature of Supreme Court litigation appears to have lent itself to printed forms, the niceties of practice seem to have dictated that papers be handwritten.

${ }^{13}$ See note 29 infra \& accompanying text. 
While reliance upon the clerks as scriveners decreased in the twenty years between Livingston's and Jay's clerkships, the time that a busy attorney could devote to the clerks' legal education probably did not increase significantly. In the course of their studies or work for their masters, clerks were confronted with a vast array of inadequately indexed sources which, only after a large expenditure of time and effort, might yield an answer to their questions. Peter Van Schaack, a close friend of Jay's, commented on his own clerkship:

For my part, how many hours have I hunted, how many books turned up for what three minutes of explanation from any tolerable lawyer would have made evident to me! It is vain to put a law book into the hands of a lad without explaining difficulties to him as he goes along. ${ }^{14}$

Van Schaack found that not more than one or two attorneys in the entire province did tolerable justice to their obligations to educate their clerks.

Jay's clerkship is most fully documented in the large number of litigation papers that were prepared in Jay's handwriting and were then filed by Kissam in the Supreme Court of Judicature. Lacking Jay's signature, the papers have survived the ravages of time and the petty thievery of autograph collectors. Sixteen of the seventeen judgment rolls filed by Kissam in the Supreme Court from June, 1764, to November, 1765, are in John Jay's hand, and the other judgment roll is in the hand of Kissam's senior clerk, Lindley Murray, the future grammarian. Jay's hand also appears on the endorsements to writs and on two writs of inquisition; from this we may conclude that his duties as junior clerk included carrying these papers to the judge or the sheriff, and thence to the Supreme Court clerk for filing. ${ }^{15}$

${ }^{14}$ Letter from P. Van Schaack to Henry Van Schaack, Jan. 2, 1769, in H. VAN SchaAck, The Life of Peter Van SchaAck, LL.D. 9 (1842). Van Schaack later established a law school at Kinderhook, N.Y., a step toward the separation of legal education from active practice and clerkship training. HaMLIN, supra note 2, at $24 \mathrm{n} .3$; see text accompanying note 130 infra. Members of the bar were not unmindful of their clerks' need for guidance. One of the William Smiths, for example, drew up a list of books to be included in a law student's course of study. Id. 61-62, 197-200; Klein, Rise of the New York Bar: The Legal Career of William Livingston, 15 WM. \& MARY Q. 357 (3d ser. 1958). Klein claims that Hamlin is incorrect in identifying William Smith, Jr., as the author, and that the list was drawn up in 1747 by William Smith, Sr.

${ }^{15}$ For a detailed listing of the judgment rolls and other documents prepared by Jay, see Colonial Lawyer, supra note 9, at 28-29, 72-73. Judgment rolls were written on 
The documentary evidence indicates that Kissam's practice involved primarily commercial matters. Only one tort claim for assault and battery was handled in the first twenty months of Jay's clerkship. One interesting manuscript, drawn up in Jay's neat hand on March 5, 1765, deals with the construction to be placed upon a will and codicil. ${ }^{16}$ Participation in the research and drafting of such a legal opinion was apparently one of the rare opportunities that John Jay had to improve his analytic skills. In a day before New York cases were regularly reported and before current English decisions received wide circulation, a lawyer's opinion was probably the closest a colonial law clerk could come to a "recent decision on the law."

The absence of reported opinions of New York courts in the colonial period and a substantial lack of law reporting from the other provinces of British North America are matters well known to students of legal history but surprising to those not familiar with colonial practice and jurisprudence. Throughout the colonies the acts of the assemblies were printed and periodically revised to eliminate repealed matter and to provide an easy guide to the statutory law of the province. Yet in New York no efforts were made during the colonial period to reduce the case law of the province to a written or printed form. ${ }^{17}$ English law

parchment measuring about six inches in width; the membranes were stitched together, and when completed the document was rolled tightly for filing in a small square slot.

${ }_{16}$ The will and codicil, executed on the same day by Elizabeth Hamilton, left the rights of beneficiary Abraham DePeyster in confusion. The will left two-sevenths of the testatrix's residuary estate to DePeyster. The codicil indicated DePeyster was entitled to a certain entailed estate and no more, provided that upon evaluation the entailed estate equaled two-sevenths of the residuary estate. The testatrix subsequently broke the entail. At her death the question arose whether she intended, in the absence of the entail, to give DePeyster nothing or two-sevenths of the residue of the estate. Kissam's opinion was that the will and codicil were to be read as one document. The provision that DePeyster take only from the entailed estate merely modified and did not supersede the bequest of the residuary estate. When the entail was broken the limitation became meaningless and thus could be eliminated. The bequest of the two-sevenths of the estate was left standing. Miscellaneous Manuscripts, Elizabeth Hamilton (New-York Historical Society, New York City).

${ }^{17}$ The first regularly reported New York cases date from 1794. J. Wallace, The RePORTERS 343 (3d rev. ed. 1855). The colonial laws of New York were published in compilations in 1694, 1718, 1752, and 1773. Session laws were also published. 1 N.Y. Colonial Laws v-vi (1894).

The only colonies with reports of pre-Revolutionary cases were Pennsylvania, Maryland, and Virginia. J. WALLACE, supra, at 339-52. Some colonies had abridgments of the statute law. See J. Bisset, Abridgment and Collection of the Acts of AsSembly of the Province of Maryland, at Present in Force (1759); J. Mercer, AN Exact Abridgement of All the Public Acts of Assembly, of Virginia, in Force and 
reports were used by New York lawyers on a fairly extensive scale, if the law libraries listed by Paul Hamlin are at all characteristic. ${ }^{18}$ English precedents were undoubtedly a rich source of law and custom in New York. In addition, English statutes, readily available in the province, had often been received into New York provincial law through usage and custom. We may speculate that what case law there might have been prior to the Revolution was concerned principally with identifying those English precedents that had been accepted in New York courts as binding upon the province. Unfortunately no extant documentation reports the opinions of the New York courts or their rulings on the law, and for that reason it is impossible to say how far they departed from the simple acceptance or rejection of English precedents.

The oral tradition of the bar preserved the major decisions in the memory of the select group that had been trained in New York clerkships. Reliance upon memory seems remarkable to lawyers of a later generation, trained to research the written precedents of courts and to present arguments based upon analysis of authorities. Yet apparently both judges and lawyers in early American courts were inclined to rely upon their mutual recollections of unreported cases. ${ }^{19}$

Even law clerks, in preparing their student notes, often failed to reduce-legal opinions to written form. A clerk would customarily copy into a "commonplace book" the necessary forms of practice, such precedents as might prove useful, and such legislative acts as bore directly upon the conduct of a law practice. ${ }^{20}$ Jay's commonplace book, begun during his first

\footnotetext{
Use, with Precedents in Law and Conveyancing (1737). Of course the acts passed at any given legislative session were printed immediately after the end of the session. In contrast, Thomas Jefferson's collection of Virginia colonial cases was not published until 1829; Josiah Quincy's collection of Massachusetts Superior Court cases from 1761 to 1772 was not published until 1865, and Thomas Harris's and John M'Henry's collection of Maryland law cases from 1658 to 1799 was not published until 1809. Historians actually know more about colonial case law today than could have been widely known in colonial America.

${ }^{18}$ HamLin, supra note 2, at 171-96.

${ }^{19} \mathrm{See}$ the colloquy between court and counsel in Kirman Holmes \& Co. v. Duncan (1788), in 1 The Papers of John Marshall 250-51 (H. Johnson ed. 1974).

${ }^{20} \mathrm{John}$ Jay, Commonplace Book (New York State Library, Albany) may be compared with the more extensive commonplace books of James Alexander (New-York Historical Society, New York City) and of Joseph Murray and John Chambers (Columbia University Law Library).
} 
twenty months as a clerk, is surprisingly brief, containing outlines for only those procedures rarely used in everyday practice. $^{21}$

Even with this extensive oral tradition, it is remarkable that no movement developed for the reporting of Supreme Court of Judicature opinions in the years immediately preceding the American Revolution. The lack of interest in perpetuating the reasoning of the courts in written records may perhaps be attributed to two factors. First, the traditional method ensured that lawyers from the mother country or sister provinces could not easily invade the monopoly of the local provincial bar. Second, the small size of the Supreme Court bar and the manner in which matters of law were adjudicated created no necessity for written opinions. While the number of admitted lawyers increased sharply prior to the Revolution, at no time did the group exceed fifty. All practiced in the City of New York and were in regular attendance at the Supreme Court and the occasional sessions of the High Court of Chancery. When the Supreme Court was sitting, Saturday of each week was designated motion day, permitting the bar to dispose of trial business during the week and to attend the motion day to hear and present arguments. ${ }^{22}$ With all of the lawyers and most of their clerks in the courtroom when motions were decided, including the important decisions on cases stated and cases reserved, very little reason remained for reduction of the decisions and opinions to written form to serve those lawyers.

In accordance with his apprenticeship agreement, Jay had permission to attend sessions of court when his office duties permitted. ${ }^{23}$ Very likely he took adwantage of this opportunity to attend the famous trial of Forsey $v$. Cunningham in 1764, a matter

${ }^{21}$ Jay singled out for particular attention the proceedings to recover possession under the act against forcible entry and detainer, not unlike summary proceedings available against a holdover tenant today; proceedings under the attachment act, which permitted prejudgment seizure of an absconding debtor's property; and proceedings on the act for preventing trespasses, a procedure somewhat in the nature of an injunction used to delay lumbering until title to realty could be ascertained. John Jay, supra note 20.

${ }^{22}$ See Minutes of the Supreme Court of Judicature, April 21, 1772-Jan. 21, 1776; Minutes of the Supreme Court of Judicature, April 18, 1769-May 2, 1772; Minutes of the Supreme Court of Judicature, Oct. 21, 1766-Jan. 21, 1769 (New York County Clerk's Office, Hall of Records, New York City). [The three volumes are collectively cited hereinafter as Judicature Minutes.]

${ }^{23}$ Although the agreement does not survive, this provision is mentioned in a letter from P. Jay to D. Peloquin, May 15, 1764, in 3 Peter Jay Letterbook, supra note 4. 
that rallied the full weight of the New York bench and bar behind the Supreme Court of Judicature and its refusal to allow an irregular mode of appeal from the verdict of a common law jury. ${ }^{24}$ Lieutenant Governor Cadwallader Colden, temporarily in charge of the province of New York, insisted that the governor's instructions ${ }^{25}$ permitted civil law appeals from the Supreme Court of Judicature as well as review through writs of error. A higher court could, in Colden's view, reverse on the facts the verdict of a jury. Chief Justice Daniel Horsmanden and all the justices of his court, with the unanimous support of the bar and the royal attorney general, opposed this measure, which they deemed an unconstitutional alteration of the form of government of the province of New York. Eventually this stand by the New York legal profession was upheld.

During Jay's clerkship the bar was caught up in another attempted exercise of imperial power-the implementation of the Stamp Act within the province. That Act required that all legal instruments and litigation papers filed with the courts be submitted on stamped paper. The New York bar, however, was not forced to decide whether to defy the imperial authorities directly by conducting business without stamps. With the stamped paper unavailable because of a tactical move by royal authorities, the courts were pressured into closing down for civil matters to avoid such a confrontation. Shutting down the courts demonstrated the profession's willingness to abet a protest against Parliament's taxes when British authority was not directly and unlawfully challenged. Because of this passive resistance,

${ }^{24} \mathrm{~J}$. Smith, Appeals to the Privy Council from the American Plantations 390-416 (1950). See also E. Alexander, A Revolutionary Conservative: James Duane of New York 26-27 (1938); A. Keys, Cadwallader Colden: A Representative Eighteenth Century Official 300-02 (1906); T. Sedgwick, supra note 11, at 121-25; Johnson, George Harison's Protest: New Light on Forsey versus Cunningham, 50 N.Y. History 61 (1969). Klein, Prelude to the Revolution in New York: Jury Trials and Judicial Tenure, 17 WM. \& MARY Q. 439 (3d ser. 1960).

${ }^{25}$ The governor's commission and instructions were drawn up by officials of the British Board of Trade and forwarded to the Privy Council for issuance in the monarch's name. Although a specific formula evolved for these documents, some changes were made over the centuries of colonial rule. Because the commission and instructions formed the basic constitutional documents of the royal colonies, these changes could, and did, have constitutional significance. The commission was promulgated upon its bearer's arrival in the colony; the instructions were made public in a selective fashion, either by virtue of an instruction that certain portions of the document be made public, or by the governor's exercise of his discretion to publicize a given instruction. See 1 Royal Instructions to British Colonial Governors 1670-1776 vii-x, 16-17, 45-46 (L. Labaree ed. 1935). 
only criminal cases, which were exempt from the tax, were tried between November, 1765, and May, 1766, when news of the repeal was received. ${ }^{26}$

The reaction of the New York bar to the Stamp Act and its earlier unified resistance to the lieutenant governor's position on appeals from the Supreme Court contrast markedly with the profession's sharp division into patriot and loyalist parties on the eve of the American Revolution. The role of the bar in these events of the 1760's indicates that both patriot and loyalist New York attorneys were opposed to the constitutional alterations being made in the name of King George III. Their differences arose from their selection of the means of opposition. Patriots decided to leave an empire that increasingly threatened the liberties they claimed as Englishmen and loyal subjects of the Crown; loyalists preferred to work within the framework of English law and constitutionalism to voice their opposition to the imperial administration.

The cessation of court business during the Stamp Act crisis forced Jay and his fellow clerks to take a vacation, a relief from the drudgery of office copying and an illustration for them of the depth of opposition to the Crown. Jay retired to his family home at Rye to read in the classics and to continue his legal studies on a more leisurely schedule. On April 25, 1766, Benjamin Kissam notified him to be ready to come to town to help reap a "Luxuriant Harvest of Law" as soon as the news of the repeal was received. ${ }^{27}$ A month was to pass before notice of royal approval of the repealing bill reached the city, reopening the New York courts to litigation. With the clerkship of Lindley Murray, Jay's senior colleague, nearing its end, Jay's return to his writing desk in May, 1766, brought the promise of new responsibilities. He continued to prepare judgment rolls, thirteen in number from May, 1766, to October, 1768, when he was admitted to the bar, but Kissam had frequent recourse to scriveners and other clerks to keep up with the stenographic tasks. Twenty-one judgment rolls are in hands other than that of

${ }^{26}$ C. Becker, The History of Political Parties in the Province of New York, 1760-1766, at 40 \& nn. 68-69 (reprint 1968); E. Morgan \& H. Morgan, The Stamp Acr Crisis: Prologue to Revolution 174-75 (1953); Morris, Legalism versus Revolutionary Doctrine in New England, 4 NEw ENG. Q. 195, 206 (1931).

${ }^{27}$ Letter from B. Kissam to John Jay, in 1 CoRrespondence, supra note 10, at 3; F. MoNAGHAN, supra note 4, at 36. 
John Jay, although his endorsements remain on most of them. ${ }^{28}$ Jay's added responsibilities included the management of Kissam's appearance dockets and the maintenance of the disbursement and fee registers of the office. ${ }^{29}$

The routine and urgency of office duties, coupled with time taken to study Kissam's law books, would not seem to have permitted much freedom for other activities. Yet John Jay took an active part in the Debating Club, a group organized by the young men of New York City to debate issues of ethics, natural law, and political theory. While a substantial portion of the membership was either law clerks or recently admitted members of the bar, ${ }^{30}$ the purposes of the Debating Club were as much social and intellectual as they were professional. In January, 1768, the Club debated the question, "Whether in an Absolute Monarchy it is better that the Crown should be elective than hereditary?" Jay argued that elective monarchy was preferable. If the son of a king was entitled to rule, Jay said, his father's interest would secure him the election. If, on the other hand, the election was contested between members of the nobility, the elective process would guarantee a contest between men of the greatest merit, for the nobility have an equal interest with the people in the government of the state. Finally, if a man was elected King in a constitutional way from among candidates of equal merit, the people would submit. To quote from the written argument of Jay and his associate, "People won't risque by Rebellion their Lives \& Property to get rid of a good King." ${ }^{11}$

The consideration of morality, law, and politics extended beyond the formal meetings of the Debating Club. Studying law in a crowded colonial seaport city, the young clerks were made aware of the functions of law as a system of police and social control. While they learned to value law as the cement of society, they also began to question the need for the harsh penalties that

${ }^{28}$ Colonial Lawyer, supra note 9, at 72-73.

29 Bill to Florus Bancker, et al., Trustees of James Duthrie, in IX Miscellaneous Manuscripts 22 (New-York Historical Society, New York City). Kissam's registers do not survive, but this bill for legal services in Jay's hand supports the theory that office management was part of a senior clerk's duties.

${ }^{30}$ The Debating Society membership included Lindley Murray, as well as Egbert Benson and Peter Van Schaack, fellow students with Jay at King's College and clerks with other New York lawyers. F. MonaGHan, supra note 4, at 39.

${ }^{31}$ Manuscripts of the Debating Society (BV Sec (Moot), New-York Historical Society, New York City). In contrast, the signers of the Declaration of Independence mutually pledged "our Lives, our Fortunes and our sacred Honor." 
were then part of the criminal law. John Jay's close friend, Robert R. Livingston, Jr., prepared a piece for publication decrying the sorry circumstances of a young woman whose death sentence had been delayed so that she might give birth to an illegitimate child, who would then be orphaned by her execution. ${ }^{32}$ But for the most part Jay's circle probably agreed with Peter Van Schaack that the "Altar of Justice requires such Sacrifices-to preserve human Society Individuals must bleed ...."33 This generation of lawyers, however, would do much to alter the most sanguinary portions of the criminal law inherited from the mother country.

In the summer of 1766 John Jay witnessed a forceful demonstration of the role of the lawyer in society: His mentor, Kissam, defended William Prendergast and his associates in the Dutchess County rent riots against charges of high treason. ${ }^{34}$ Tenant resistance to the New York system of land tenure and to suspect claims of the Dutchess County landholders intensified when the courts were closed in response to the Stamp Act. When the courts reopened in the spring of 1766, the sudden and widespread collection and ejectment effort stirred additional resentment. By summer, resistance to payment resulted in a violent outbreak against lawful authority in Dutchess County and elsewhere. The May riot on the Livingston Manor compelled the royal governor to send the Twenty-Eighth Regiment of regular troops up the Hudson River to put down the rebellion against the civil authorities. Several militiamen, supporting the regular troops, were killed in the affray with the tenants, and Sir Henry Moore, the governor, appointed a special Court of Oyer and Terminer to try the rebel leaders, including Prendergast. ${ }^{35}$ This

${ }^{32}$ Manuscript, Nov. 3, 1768, [Box 1] Livingston Papers, (New-York Historical Society, New York City).

${ }^{33}$ Letter from P. Van Schaack to Peter Silvester, Jr., Aug. 1, 1768 (Van Schaack Papers, Columbia University Libraries, Special Collections).

${ }^{34}$ See I. Mark, Agrarian Conflicts in Colonial New York 135-148 (1940); Mark \& Handlin, Land Cases in Colonial New York, 1765-1767, The King v. William Prendergast, 19 N.Y.U.L.Q. REv. 164 (1942).

${ }^{35}$ The court that tried the Dutchess County rioters was one of Oyer and Terminer, and not merely a special sitting of the Supreme Court of Judicature. See letter from Gov. Moore to the Lords of Trade, Aug. 12, 1766, in 7 Documents RELAtive to the Colonial History of THE State of New York 849 (E. O'Callaghan ed. 1856) [hereinafter cited as Doc. Rel. Col. HIST. N.Y.]; letter from Gov. Moore to Sec. Conway, July 14, 1766, in 7 Doc. Rel. Col. Hist. N.Y. 845. William Smith, Jr., then a private attorney, recounted his own reluctant acceptance of a seat on the special court. Historical Memoirs from 16 March 1763 to 9 JuLy 1776 of William Smith 33-34 (W. Sabine ed. 1956) [hereinafter cited as WILLIAM SMITH]. 
court, armed with commissions to try high crimes and misdemeanors, was separate from the Supreme Court of Judicature, which did not exercise criminal jurisdiction in these matters. Composed of specially commissioned justices, it was heavily balanced in favor of the landlord interests, and a number of the future leaders of the American Revolution in New York served on this tribunal. ${ }^{36}$ William Prendergast challenged the members of the court: If opposition to government was rebellion, then no member of the court was qualified to sit in his case. ${ }^{37}$

To that Court of Oyer and Terminer rode Benjamin Kissam, entrusting his cases before the Supreme Court and his court appearances to John Woods. He had taken upon himself the awesome burden and unpopular task of defending Prendergast. To Jay, his clerk, he wrote, "[W]hat their fate will be, God only knows; it is terrible to think that so many lives should be at stake upon the principles of a constructive murder: for I suppose that the immediate agency of but a very few of the party can be proved." 38 The reference to constructive murder indicates that Kissam was engaged in the defense of Prendergast's followers, which began on August 14, 1766. ${ }^{39}$ It is not known whether Kissam took part in the cross-examination of the Crown witnesses. He did advance a strong argument that Prendergast and his associates had been asserting their private rights rather than staging a public demonstration to redress a public grievance or to alter the law. Under English law, riots over private grievances would not subject the participants to the penalties for high treason. ${ }^{40}$ Kissam's abilities could not prevail against the contrary

${ }^{36}$ William Smith's account indicates that the court had a large bench, including both him and his father, a Supreme Court justice. William SMITH, supra note 35, at 33-34. Mark and Handlin state that the Court of Oyer and Terminer consisted of Chief Justice Daniel Horsmanden, John Watts, William Walton, Oliver DeLancey, Joseph Reade, William Smith, Whitehead Hicks, and John Morin Scott. Mark \& Handlin, supra note 34 , at 167 n.3.

${ }^{37}$ The remark, no doubt based on hearsay evidence, is recounted in Captain John Montresor's journal. THE MonTresor Journals 384 (New-York Historical Society Publication Fund No. 14, 1881).

${ }^{38}$ Letter from B. Kissam to John Jay, Aug. 25, 1766, in 1 W. JAY, The Life of JoHN JAY 19, 21 (1833) [hereinafter cited as LIFE]. York City).

${ }^{39}$ Notes on July 1766 Assizes, Dutchess County (New-York Historical Society, New

${ }^{40}$ The citations used by Kissam are reproduced in Mark \& Handlin, supra note 34, at 194. The works are Kelyng's Reports 75 [Messenger's Case], 84 Eng. Rep. 1087 (Exch. Ch. 1680); Popham's Reports 122 [Case of Bradshaw \& Burton], 79 Eng. Rep. 1227 (K.B. 1597); Sir Michael Foster's Report and Discourses 211 (1762); 1 W. Hawkins, A Treatise of the Pleas of the Crown 34, 37 (1724-26). For a discussion 
contentions of the Crown attorneys, nor could he successfully refute the large number of witnesses obtained by the Crown, in a number of cases through promises of immunity from prosecution. ${ }^{41}$ The case ended with Prendergast's conviction and sentence to be hanged, castrated, disemboweled, beheaded, and quartered. ${ }^{42}$ Fortunately for him, the execution was suspended by the governor and he was subsequently pardoned by the Crown. ${ }^{43}$

John Jay's attitudes toward the Prendergast case are not known, but Kissam's letter to him concerning the trials conveyed a compassion and humanity that must have impressed his clerk. The letter reveals a warm-hearted man, shocked by the violence of the agrarian revolt, but nevertheless reluctant to permit a wholesale execution of the participants to satiate the thirst for revenge that permeated the propertied classes.

While training in legal draftsmanship and litigation formed the backbone of John Jay's legal education, clerkship had been for him a time of maturation and growing sensitivity to the social and political consequences of the law in colonial New York.

\section{ADMISSION TO THE BAR AND Commencement of Practice}

Events during Jay's clerkship undermined the assumptions of the agreement he had made with Benjamin Kissam in January, 1764. Under its terms Jay was to serve a five-year term as a clerk before he would be certified for examination by his mentor. ${ }^{44}$ A 1767 rule of the Supreme Court of Judicature required that college graduates, a class into which Jay fell, were to serve only three years. ${ }^{45}$ On the other hand, the suspension of Jay's clerkship during the Stamp Act crisis deprived Kissam of his clerk's services. Kissam and Jay probably considered these variables and agreed that Jay would apply for admission to the bar about six months earlier than originally planned. Their parting appears to have been cordial, for thereafter Kissam was most

of the law of treason in the colonies, see Hurst, Treason in the United States (pts. 1-3), 58 Harv. L. Rev. 226, 395, 806 (1944-1945).

${ }^{41}$ Appearance Bond, Aug. 1, 1766, Miscellaneous Manuscripts, Dutchess County (New-York Historical Society, New York City).

42 MARK, supra note 34, at 147.

${ }^{43}$ S. Lynd, Anti-Federalism in Dutchess County, New York 50-51 (1962).

44 The five-year term was required by the Agreement of the Bar of New York City, concluded Jan. 5, 1764, in Hamlin, supra note 2, at 163.

${ }^{45}$ HamLin, supra note 2, at 39. 
helpful in securing employment for his former clerk, and in some instances, referring cases to him.

In the fall of 1768 Benjamin Kissam recommended Jay for admission to the bar. Although the 1764 agreement concerning admission required that the candidate's name be endorsed for examination, it is unclear whether such examinations were in fact conducted. Where the attorneys in New York City were personally aware of the abilities of the applicant, the examination may have been eliminated entirely. ${ }^{46}$ We do not have any record of Jay's being examined, but on October 26, 1768, Governor Sir Henry Moore, "being well assured of the Ability and Learning of John Jay, Gentleman," 47 appointed him an attorney-at-law and authorized him to appear in all of the provincial courts of record in accordance with the laws of New York and England. ${ }^{48}$ Now a fully qualified attorney, Jay stood at the threshold of his career in the law, a profession he believed was to be his life's work.

Jay's prospects for success may have fallen considerably during his clerkship. When Jay entered Kissam's office the Supreme Court of Judicature bar was a relatively small group of thirty-six attorneys, averaging thirty-eight years of age, and closely related by blood or marriage to the large landowners and prosperous merchants of the province. ${ }^{49}$ Their numbers had been purposely restricted by the 1756 bar agreement eliminating New York clerkships. ${ }^{50}$ John Jay would have gained ready acceptance into this group by virtue of his social position, ${ }^{51}$ and he also would

${ }^{16}$ For a discussion of admissions procedures, see id. 38, 50; Letter from P. Van Schaack to Peter Silvester, Aug. 1, 1768 (Van Schaack Papers, Columbia University Libraries, Special Collections).

${ }^{47}$ Jay's license to practice law, signed by Governor Moore, is in the Columbia University Libraries, Special Collections.

${ }^{48}$ Five days later Jay appeared in the Supreme Court of Judicature and produced his license. The presiding justice then administered the prescribed oaths and declaration, and the newly admitted attorney signed the roll of attorneys. Minutes of the Supreme Court of Judicature, Oct. 21, 1766-Jan. 21, 1769, at 567 (New York County Clerk's Office, Hall of Records, New York City); Roll of Attorneys, Oct. 26, 1754-June 3, 1847, Ledger J, Parchment Roll 1 (New York County Clerk's Office, Hall of Records, New York City).

${ }^{49}$ For a listing of Supreme Court attorneys, with age, education, and family relationships, see Colonial Lawyer, supra note 9, at 253.

${ }^{50}$ See notes 2-6 supra \& accompanying text.

${ }^{31} \mathrm{John}$ Jay was related to the leading landowning and mercantile families of New York. Through his paternal grandmother he was related to the Bayards, his mother was a member of the Van Cortlandt family, and his first cousins included DePeysters, DeLanceys, and Stuyvesants. See generally L. Wells, The Jay Family of LaRochelle AND NEW YORK (1938). 
have prospered as older members of the Supreme Court bar retired from practice or were appointed to the Supreme Court. While Jay was a clerk, however, this monopoly of the law began to crumble, first with the liberalized clerkship rule of $1764^{52}$ and subsequently with the 1767 reduction of college graduates' clerkships to three years. ${ }^{53}$ In 1767 the number of admissions rose to three a year from one a year for the preceding period of two years. Although only Jay and Livingston were admitted in 1768, six attorneys were admitted in 1769 , and twelve in $1770 .{ }^{54}$ The net result was that from 1765 to 1770 , twenty-five lawyers were added to the original, small group of seasoned practitioners.

The neophytes, whose preparation and abilities varied greatly, were all in competition for the limited legal business that was likely to fall to new practitioners. As the number of attorneys practicing before the Supreme Court of Judicature increased, the economic life of New York settled into a lethargy caused by new British commercial restrictions, ${ }^{55}$ the Townshend Acts, and a decreasing money supply. ${ }^{56}$ Not surprisingly, of the twenty-five men admitted to practice from 1765 to 1770 , only eleven continued in active practice before the Supreme Court. ${ }^{57}$ That Jay remained within this active group evidences not only his abilities and tenacity, but also his capacity to attract clients and secure business on referral from other attorneys.

Jay's first step toward survival was the formation of a partnership, a form of practice almost unheard of in colonial New York, with his college classmate and close friend, Robert $\mathbf{R}$. Livingston, Jr. Even with the combined clientele of the Jay and Livingston families, the partnership seems to have made a precarious start. ${ }^{58}$ In January, 1769 , business was so modest that Jay was able to conduct it alone while Livingston traveled to his ancestral home at Clermont. ${ }^{59}$ The April, 1769 motion calendar

${ }^{52}$ See note 6 supra \& accompanying text.

${ }^{53}$ See note 45 supra \& accompanying text.

${ }^{54}$ Minutes of the Supreme Court of Judicature, Oct. 21, 1766-Jan. 21, 1769, at 28, 29, 50, 247, 567, 606-07; Minutes of the Supreme Court of Judicature, April 18, 1769-May 2, 1772, at 15,107, 113, 186, 188, 194, 243, 288, 319 (New York County Clerk's Office, Hall of Records, New York City).

${ }^{55}$ Klein, supra note 14 , at 354 .

${ }^{56} 5$ C. BECKER, supra note 26 , at 26, 53-94.

${ }^{57} \mathrm{See}$ Judicature Minutes, supra note 22.

${ }^{58}$ Contra, 1 Life, supra note 38, at 21.

${ }^{59}$ Letter from John Jay to R.R. Livingston, Jr., Jan., 1769, [Box 1] Livingston Papers (New-York Historical Society, New York City). 
lists only four Jay-Livingston cases. Of these, at least two originated among Jay's relatives. ${ }^{60}$ Had the partners begun practice without family backing and pooling their respective cases, both would have been quickly forced out of business. The partnership arrangement continued until October, 1771, when Jay's cases were ruled off in the joint law register that he and Livingston maintained for their Supreme Court of Judicature matters. ${ }^{61}$ In 1771, Jay paid as much in clerk's fees for his individual cases as the Jay-Livingston firm had paid to the same clerk during the entire three years of its existence. ${ }^{62}$

During the partnership period matters other than law practice apparently occupied most of Jay's time. He rapidly replaced his elder brother, Augustus Jay, as the New York City representative of Jay family interests. ${ }^{63}$ During the summer and fall of 1769 he was actively involved as clerk to the New York-New Jersey Boundary Commission, a royal body appointed by the Privy Council to fix the northern boundary of New Jersey. As clerk, Jay was expected to keep a thorough account of all of the proceedings, recording the activities of the commissioners in a minute book and preserving the written interrogatories of witnesses for future consideration. ${ }^{64}$ Because the Commission followed civil law procedure and appeals were permitted from it to the Privy Council, Jay's clerkship experience with litigation papers for the Vice-Admiralty Court, which followed similar procedures, proved most valuable. ${ }^{65}$ Jay's work with the Commission gave him a solid grounding in the operations of a mixed com-

${ }^{60}$ Minutes of the Supreme Court of Judicature, April 18, 1769-May 2, 1772, at 53 (New York County Clerk's Office, Hall of Records, New York City).

${ }^{61}$ The dissolution of the partnership began in January, 1771, when Jay and Livingston appeared in court separately as well as in pursuit of partnership matters. Their partnership register was closed in October, 1771. Law Register of John Jay and Robert R. Livingston, Jr. (BV Sec. New-York Historical Society, New York City); Minutes of the Supreme Court of Judicature, April 18, 1769-May 2, 1772, at 336, 384-85, (New York County Clerk's Office, Hall of Records, New York City).

${ }^{62}$ Entries for John Jay and Jay \& Livingston in Account Book of George Clark, Clerk of the Supreme Court (New-York Historical Society, New York City).

${ }^{63}$ See John Jay's advertisements to rent family property, in N.Y. Gazette and Weekly Post Boy, Feb. 8, 1768; N.Y. Mercury, Jan. 19, 1767; id. Jan. 25, 1768. See also letter from Frederick Jay to John Jay, June 5, 1769 (Columbia University Libraries, Special Collections).

${ }^{64} \mathrm{~A}$ complete set of minutes, interrogatories and other Boundary Commission papers is in [Box 7] Jay Papers (New-York Historical Society, New York City). For a discussion of the commission and its proceedings, see Colonial Lawyer, supra note 9, at 100-17.

${ }^{65}$ See Johnson, Civil Procedure in John Jay's New York, 11 AM. J. Legal Hist. 69, 79 (1967). 
mission. Colonial, and particularly Jay's, familiarity with this British imperial institution laid the basis for use of the device not only for the settlement of interstate boundary disputes under the Articles of Confederation, but also for adjustment of complex issues in international disputes. ${ }^{66}$

Benjamin Kissam, one of the agents selected by the New York General Assembly to argue the province's case, may have prompted Jay's appointment as clerk to the Boundary Commission. Certainly Kissam's referrals of law cases to Jay in the years following 1769 evidence his continuing encouragement of the young attorney. While Jay was trying some cases in the up-river counties, Kissam wrote him:

If it was not for you, or some other such apostolic lawyer, my clients would be left in the lurch this court [sic], as I am afraid I cannot attend myself. But, sir, you have now a call to go forth into my vineyard; and this you must do, too, upon an evangelical principle-that the master may receive the fruits of it. ...

... I wish you good success with my consignments, and hope they'll come to a good market. If they don't I am sure it will not be the factor's fault; and if my clients' wares are bad, let them bear the loss. ${ }^{67}$

Despite Kissam's levity, he clearly took a considerable risk in trusting the trial of cases on circuit to his former clerk. The circuit ridings of the Supreme Court of Judicature resulted in the returns of jury verdicts to the court clerk, ready for the formal imposition of judgment by the court en banc; consequently, it was quite easy to do irreparable damage to the case during the trial on circuit. No greater compliment could be given to Jay's abilities than this vote of confidence by his former master.

\section{Success at THE Bar}

From 1771 to 1775 John Jay established a successful and remunerative practice, ${ }^{68}$ and by the eve of the Revolution he was

${ }^{66} \mathrm{~J}$. SMITH, supra note 24, at 462-63. For a discussion of Jay's association with the mixed commission, see Lillich, The Jay Treaty Commissions, 37 ST. JoHn's L. Rev. 260 (1963). 22.

${ }^{67}$ Letter from B. Kissam to John Jay, Nov. 6, 1769, in 1 Life, supra note 38, at 21,

${ }^{68}$ For a discussion of the mechanics of colonial law practice, see Johnson, supra note 65 . 
among the better known attorneys in the province of New York. Although family connections and referrals from Kissam played a part in his success, only hard work and determination elevated him above the level of his contemporaries. Jay's first step as an independent practitioner was to restrict the geographical area of his practice. He left the Dutchess County causes with his former partner, Livingston, ${ }^{69}$ concentrating his country practice in the Common Pleas Court of Westchester County. ${ }^{\mathbf{7 0}}$ At the November, 1770, term of the Supreme Court of Judicature he opened eighteen cases in his individual name, and at the following term in New York City he added an additional eighteen cases to his independent trial docket. ${ }^{71}$ The increased case load soon took its toll on Jay's health. From the fall of 1770 until the summer of 1771 he was under the care of three doctors for a swelling of muscles in his neck and a lingering fever. ${ }^{72}$ The illness conquered, he returned to the task of increasing his store of pending cases. By late 1773, he had reached the apparent peak of his caseload, with 136 cases pending in the Supreme Court of Judicature and 118 pending in the Westchester County Court of Common Pleas. ${ }^{73}$ Subsequent to this rapid expansion, Jay seems to have been content to open relatively fewer cases in the years 1773 and 1774 . The loss of registers and court minutes limits the statistics available on his practice for the years from 1774 to 1776 , but it seems likely that after late 1773 the time consumed by longstanding litigation curtailed the number of new cases he could open.

The pending cases in Jay's office included nearly every phase of civil litigation. Of those with identifiable subject matter, fifty-one were actions of debt on writings obligatory, twenty-five

${ }^{69}$ D-F Minutes of the Dutchess County Court of Common Pleas, 1766-1775 (Dutchess County Clerk's Office, Poughkeepsie, N.Y.).

${ }^{70}$ Minutes of the Westchester County Court of Common Pleas, 1723-1773; Minutes of the Westchester County Court of Common Pleas, 1774-1793 (Westchester County Clerk's Office, White Plains, N.Y.).

${ }^{71}$ Statistics on case openings in the Supreme Court are based on returns of capias ad respondendum writs reflected in the Minutes of the Supreme Court of Judicature, April 18, 1769-May 2, 1772, (New York County Clerk's Office, Hall of Records, New York City); Minutes of the Westchester County Court of Common Pleas, 1723-1773 (Westchester County Clerk's Office, White Plains, N.Y.). A writ book, also known as a praecipe book, provides the data for the Mayor's Court of New York City.

${ }^{72}$ Letter from John Jay to Samuel Kissam, Aug. 27, 1771, in Monaghan, Samuel Kissam and John Jay, 25 CoLUM. U.Q. 127, 130-31 (1933).

${ }^{73}$ For a graphic representation of Jay's case openings and pending caseload in various courts, see Colonial Lawyer, supra note 9, at 256-64. 
were actions in trespass for assault and battery, eleven were actions in ejectment, and nine were proceedings in certiorari. ${ }^{74}$ Jay's practice involved him in minor litigation ${ }^{75}$ as well as in the most significant cases of the period.

In January, 1773, Jay became defense counsel for Nathaniel Underhill in King $v$. Underhill, a case instituted by Attorney General John Tabor Kempe to compel the Supreme Court to render a strict interpretation of the suffrage requirements in Westchester borough elections. ${ }^{76}$ Although the case was litigated by several well-known attorneys, and enjoyed considerable prominence at the time, its precise details appear to have been lost. Jay's principal service to Underhill, whose election as mayor of the borough was being challenged, was to secure two continuances until July, 1773. By then, the Crown Attorney seems to have lost interest in the case, and no further effort was made to try it. Underhill remained in office until well after the State of New York had declared its independence. In 1773 and 1774 Jay also represented the officials of the town and borough of Westchester in a mandamus action to order them to admit Gilial Honeywell and Isaac Legget to the offices of aldermen. ${ }^{77}$ Jay used

${ }^{74}$ Law Register of John Jay (New York State Library, Albany). Certiorari in colonial New York practice was used by the Supreme Court of Judicature as a form of review of the administrative decisions of inferior courts of common pleas and general sessions. In all cases examined the certiorari was issued to the justices of the inferior court as a collegiate group; the normal form of appeal in common law matters was by writ of error.

${ }^{75}$ In the assault and battery action of Budd v. Tompkins, Jay defended three Westchester men charged with beating a schoolmaster who had sued them for his salary. Jay promptly moved for and obtained a change of venue from New York County, where his clients were imprisoned, to Westchester County, where they were better known. His affidavit in support of the motion alleged that all of the material witnesses were in Westchester. The convenience in taking testimony, of course, was secondary to the advantage of having a jury empaneled in Westchester to try the case. There was conflicting evidence concerning the original obligation upon which the schoolmaster had brought his action and concerning the defendants' claim that he had stolen corn from them. The jury, swayed by Jay's argument and influenced no doubt by sympathy for their neighbors, held for Jay's clients. Law Register of John Jay, supra note 74, at 22; [A-B] Lawsuits, John Tabor Kempe Papers (New-York Historical Society, New York); Minutes of the Supreme Court of Judicature, Apr. 18, 1769-May 2, 1772, at 306 (New York County Clerk's Office, Hall of Records, New York City). For a full discussion of the case, see Colonial Lawyer, supra note 9, at 148-51.

${ }^{76} \mathrm{H}$. Dawson, Westchester County, New York During the American Revolution 4 (1886); G. Pellew, John Jay 18-19 (1890); 1 J. Sparks, The Life of GoUVERNEUR Morris 20 (1832); Law Register of John Jay, supra note 74, at 176; [S-U] Lawsuits, John Tabor Kempe Papers (New-York Historical Society, New York City).

${ }^{77}$ Minutes of the Supreme Court of Judicature, Apr. 21, 1772-Jan. 21, 1776, at $101,131,153$ (New York County Clerk's Office, Hall of Records, New York City). 
procedural motions to exclude the pair from office for the period from July, 1773, to April, 1774, but he was unable to prevent the Crown from eventually directing their installation. These two cases involving royal officials' meddling with local elections may have enhanced Jay's recognition and popularity throughout the province.

Jay was also involved in one of the most important cases of the day in the provincial High Court of Chancery, Bloomer $v$. Hinchman, a struggle by proxy between the vestry and the governor for control of a parish. When the first rector of the parish ${ }^{78}$ received a call to another church, the vestry installed a Presbyterian divine in his place. The governor, however, intervened. Without vestry concurrence, the governor, who had the ecclesiastical power of nomination of clergymen by virtue of his commission, appointed as rector the Reverend Mr. Joshua Bloomer, an Anglican. The vestry countered by withholding Mr. Bloomer's salary. Caught between the two contending forces, $\mathrm{Mr}$. Bloomer was forced by necessity to commence a suit against the vestrymen to collect his arrears in salary. ${ }^{79}$ When Jay entered the case on Bloomer's behalf is unknown, but by December, 1771 , Jay had come to the conclusion that he was being ignored by John Tabor Kempe, another attorney retained by Bloomer. Affronted at not being consulted at an important stage of the litigation, Jay dressed Kempe down in indelicate terms, drawing a sharp rebuke from Jay's senior counsel. Jay righteously continued to demand an explanation, which Kempe steadfastly refused to give. ${ }^{80}$ The interchange indicates that Jay, whose social position was apparently superior to Kempe's, was willing to risk the enmity of the older man to protect his reputation at the bar. No further record of Jay's participation exists, although the biographer of his co-counsel, James Duane, gives Jay credit for participation in later phases of the case. ${ }^{81}$ As might have been

${ }^{78}$ Established and incorporated in the spring of 1761 , the parish, now known as Grace Church in Jamaica, had the Reverend Mr. Samuel Seabury as its first rector. A Thomas Hinchman, probably a relative of the defendant in this chancery case, was among the first vestrymen. Vestry Minutes and Register, 1764-1862, at 2 (Grace Church Parish Hall, Jamaica, N.Y.). Mr. Seabury was called to a Westchester County church. E. AlexANDER, supra note 24, at 22.

${ }^{79}$ E. Alexander, supra note 24, at 22; H. Onderdonk, JR., Antiquities of the Parish Church, Jamaica 68 (1880); 4 Minutes of the High Court of Chancery 46, 64, 69 and BM-1425-B (New York County Clerk's Office, Hall of Records, New York City).

${ }^{80}$ The interchange of letters is in [Box 2] Sedgwick Papers (Massachusetts Historical Society, Boston).

${ }^{81}$ E. AlEXANDER, supra note 24, at 22. Jay's connection with the litigation was prob- 
anticipated, the governor, sitting in his capacity as chancellor, upheld his constitutional right to appoint rectors of the established church in the province of New York. The vestry's appeal to the Privy Council was interrupted by the outbreak of the American Revolution.

Although modest in relation to his practice in the Supreme Court of Judicature, Jay's practice in the Court of Chancery was quite respectable by 1772 . Since fees in Chancery were slightly higher than those in Supreme Court practice, the added effort and care required to prepare a Chancery case were well compensated.$^{82} \mathrm{Had}$ his practice continued beyond the Revolution, it is quite likely that Jay would have achieved a distinguished position as a counselor in the Chancery Court; his meticulous work habits $^{83}$ in drafting pleadings would have made him a most valuable adviser.

While practice in Chancery required exhaustive attention to detail, matters before the Prerogative Court of the province tended, for the most part, to be mere formalities. Acting as ordinary $^{84}$ for the province of New York, the governor bore the responsibility of admitting wills to probate and granting letters of administration for intestate estates. The primary activity of

ably as a counselor in the chancery, responsible for arguing the case and helping to draw the pleadings and interrogatories.

${ }^{82}$ Compare Chancery fees with Supreme Court fees, in William Livingston, Cost Book in the Supreme Court of Judicature, 1759-1772, at 438-39, 485 (New York Public Library). For a discussion of the constitutional struggle between the New York Council and the Assembly concerning the right to set Chancery and Admiralty Court fees, see 1 P. Hamlin \& C. Baker, Supreme Court of Judicature of the Province of New York 1691-1704, at 269-71 (New-York Historical Society Collections No. 78, 1945). In 1710 the conflict was resolved in favor of fees established by ordinance rather than by act of the Assembly. In Prerogative Court, the fees remained those established by a 1693 statute that had been ratified by a subsequent ordinance and royal approval. Johnson, The Prerogative Court of New York, 1686-1776, 17 AM. J. LEGAL HIST. 95, 101-02 (1973).

${ }^{83}$ Later when he was Chief Justice of the United States, Jay wrote to explain to his son how a letter should be answered. "[W]hen you answer a Letter, it is always advisable to read it over carefully and attentively, and to mark accurately what part it may be proper or necessary to answer, and what not." Letter from John Jay to Peter Augustus Jay, Dec. 4, 1790 (collection of John Jay DuBois, Rye, N.Y.). While he was a college student Jay kept a writing desk near his bed to make changes in compositions that occurred to him during the night. I LIFE, supra note 38, at 13.

${ }^{84}$ In ecclesiastical court practice the ordinary was the official in charge of a diocese or archdiocese and thus was empowered to act in probate matters. His jurisdiction could be limited by specific grant of a "peculiar" authority to another official. The ordinary in England was most commonly a bishop. See generally W. NELSON, Lex Testamentaria (1724). Although the bishop of London had general ecclesiastical supervision of New York, the authority to grant probate and letters testamentary in the province was vested in the royal governors. Johnson, supra note 82 , at 97. 
the Prerogative Court was the recording of wills, letters testamentary, and letters of administration. The court also had the power to compel an executor to file an inventory at the suit of legatees, a jurisdiction rarely exercised because it was shared with the High Court of Chancery and the Supreme Court of Judicature. The three cases noted in Jay's law register concerning the Prerogative Court involve such applications to the court for relief. ${ }^{85}$

Supplemented by an extensive backlog of cases in the Westchester County Court of Common Pleas and the Mayor's Court of the City of New York, John Jay's pending cases in the central courts at New York City promised him a comfortable living for several years to come. On the eve of the Revolution the loyalist Supreme Court Justice, Thomas Jones, noted that Jay was a gentleman of eminence in the law who had a sufficiency of ambition, a proper share of pride, and a reverence for the British constitution in church as well as state. ${ }^{86}$ Another loyalist claimed that Jay's practice yielded him about $£ 1,000$ per annum, no mean sum when it is compared to the $£ 1,287$ per annum attributed to the veteran lawyer William Livingston or the $£ 1,400$ attributed to James Duane. ${ }^{87}$

\section{Continuing Legal Education}

The extreme pressures of an active practice, coupled with the increasing competition for cases, could easily have robbed the colonial New York bar of its energy and interest in selfimprovement. Yet men who had learned their law as clerks, squeezing self-education in amidst an avalanche of paper and heavy responsibilities, were able to cope with day-to-day practice and still find time to enhance their understanding of the law through reading and discussion. John Jay was quite representative of the group of colonial lawyers that made the decade before the American Revolution one of the golden ages of legal learning in the province. They did this through book purchases and participation in a legal discussion group called the Moot.

${ }^{85}$ Law Register of John Jay, supra note 74 . For the procedures available to compel the filing of an inventory, see Johnson, supra note 82, at 138-39.

${ }^{86}$ I $\mathrm{T}$. Jones, History of New York During the Revolutionary War 35 (E. DeLancey ed. 1879).

${ }^{87}$ Klein, supra note 14 , at 355 . Thomas Barclay claimed before the Commissioners on Loyalist Claims that Jay offered him a partnership and that Jay's business amounted to more than $£ 1000$ per year. Hamin, supra note 2, at 94 . 
In the mid-1700's, the law of the province of New York was derived from the common and statutory law of England, as modified by the acts of the New York General Assembly and as either received or rejected by the usages of the courts in New York. ${ }^{88}$ Since the opinions of New York courts were not available in printed reports, it is not surprising that the bulk of the volumes in John Jay's law library was printed in England and pertained to English common law. These materials were cited before the courts of the province, formed the basis for discussion at the Moot, and were the fundamental law for all practical purposes. Jay had been fortunate to inherit a good working library from his godfather and uncle, former Supreme Court Justice John Chambers, who died in $1764 .^{89}$ This legacy included all the volumes of the reports of Sir Edward Coke, Sir George Croke's Reports, the two then-published volumes of Peere Williams's Reports, and reports of Keilwey and Kelyng. Among the Chambers treatises in Jay's library were Matthew Hale's History of the Pleas of the Crown, Giles Jacobs' Lex Mercatoria, and William Nelson's Lex Testamentaria. Not content to rely upon this good basic collection, Jay conducted a program of purchases from 1770 through 1774 . Jay first had substantial earnings from practice in 1771 , and he seems to have spent part of his income from that year on the expansion of his library. Thereafter he apparently limited purchases to newly published case reports. For example, in 1773 he purchased William Salkeld's Reports, the new edition of which had been published in London earlier in the same year. In 1772, Jay purchased the third volume of Peere Williams's Reports, which had been published in 1768 .

Jay's membership in the Moot also greatly advanced his legal education. From 1770 to 1774 , this select group of lawyers met to debate points of law. At the same time they agreed to refrain from arguing the political issues that sharply divided them and soon destroyed not only the Moot, but royal government in New York and the society they knew. Jay's name is listed as a charter member of the Moot. From 1771 to 1772 he served as secretary of the organization. ${ }^{90}$ The group's debates illustrate the complex

${ }^{88}$ For a discussion of the process of reception and modification, see 1 P. HaMLIN \& C. BAKER, supra note 82 , at $378-412$.

${ }^{89}$ The discussion of Jay's library is based upon a physical examination of the extant library (Columbia University Law Library, Treasure Room). For a complete catalog, see Colonial Lawyer, supra note 9, at 264-72.

${ }^{90}$ Minutes of the Moot (private collection of Dr. John Jay DuBois, Rye, N.Y.) 
problems of colonial practice that were relatively unknown in England. For example, the Moot debated whether a New Jersey decedent's estate, represented by a New Jersey executor, might be sued in New York for the decedent's obligation when the executor happened into New York. The members of the Moot considered the English rule that an executor may be sued even before a will is admitted to probate by the ecclesiastical court. Despite that rule and its implication that an executor is amenable to suit outside the jurisdiction granting representative capacity, they held that a New Jersey executor could be sued in his representative capacity only in New Jersey. New York and New Jersey, they recognized, had a special jural relationship quite unlike that between English counties or dioceses. The interprovincial problem was unique, and English precedent offered no solution.

Another Moot discussion of interprovincial legal relationships demonstrates that conflict of laws was among the legal issues foremost in the minds of colonial practitioners. The debate involved the effect of a New Jersey insolvency proceeding upon the rights of creditors residing in the province of New York. The hypothetical situation posed was that a New Jersey debtor, having obtained relief in New Jersey, then moved to New York, where he was sued by his New York creditors, some of whom had contracted with him in New Jersey. Could the New York creditors sue the New Jersey expatriate in spite of his release under the laws of the province of New Jersey? The Moot opined that as to debts actually contracted in New Jersey, there could be no recovery. Creditors who had appeared in the New Jersey insolvency proceeding would also be precluded from asserting their rights against the New Jersey insolvent. From the Moot's discussion we may assume that the situs of the making of the contract determined the law controling insolvency proceedings against the debtor. An appearance in the New Jersey insolvency proceeding by a creditor who had made his contract in New York, however, would constitute submission to the jurisdiction of the New Jersey court and a consent to the debtor's discharge under New Jersey law. New York creditors who had taken the precaution of contracting in New York, and who had

[hereinafter cited as DuBois Minutes]; Minutes of the Moot (BV Sec (Moot), NewYork Historical Society) [hereinafter cited as Society Minutes]. For a more detailed treatment of the debates, see Colonial Lawyer, supra note 9, at 177-85. 
not waived their rights by an appearance in the New Jersey insolvency proceeding, retained their privilege to institute collection actions in New York.

The Moot also struggled with difficult problems of New York law that continue to puzzle legal historians. ${ }^{91}$ One debate that ended without a resolution concerned the 1677 English Statute of Frauds $s^{92}$ and its applicability to the province. The statute, which antedated the creation of a New York General Assembly, did not expressly apply to His Majesty's dominions. Thus, identification of the parts of the statute that did apply depended on the arcane process of statutory reception-a combination of legal mythology, pragmatism, and mechanics. Resolution of questions of reception required fine constitutional reasoning as well as precise knowledge of the unwritten usages of the colonial practice. Evidence apparently unknown to the Moot, for instance, indicates that New York courts had, by usage, selectively adopted certain portions of the 1677 English Statute of Frauds. ${ }^{93}$

Although the debating functions of the Moot were of primary importance, the organization also served more public and regulative purposes. Its membership made it the outstanding professional organization in colonial New York, and it took strong positions against attorneys' advancing expenses on behalf of their litigating clients. ${ }^{94}$ This stand coincided with the rules against champerty that Jay and others were already following. The limitation tended to remove the lawyer from the more commercial aspects of practice and to elevate him to a position similar to that of the English barrister. The Moot also evidenced concern for the bar's public relations. When court cryer Richard Wenman found himself in financial distress because attorneys

\footnotetext{
91 See, e.g., Beers v. Hotchkiss, 256 N.Y. 41, 175 N.E. 506, (1931) (Cardozo, C.J., on the Statute of Frauds).

9229 Car. 2, c. 3. See generally Costigan, The Date and Authorship of the Statute of Frauds, 26 HaRv. L. Rev. 329 (1913).

${ }^{93} \mathrm{New}$ 'York had accepted that some witnesses, but not necessarily three, were required to validate a will of real property. Also accepted in New York were the English statute's requirements for nuncupative wills of personalty. Johnson, supra note 82, at 115-17. In 1774 the Assembly declared that the statute had been received by usage and then proceeded to amend it. Act of March 19, 1774, ch. 1678, 5 N.Y. Colonial Laws 689. An earlier attempt to enact an omnibus reception of those English statutes passed after the establishment of the provincial legislature was disallowed as an affront to royal rights. Act of Dec. 24, 1767, ch. 1327, 4 N.Y. Colonial Laws 953, disallowed, Order of Dec. 9, 1770, $\S 168,5$ Acts of the Privy Council of England (Colonial Series) 284.

${ }^{94}$ Society Minutes, supra note 90 , at 17-18.
} 
had failed to pay his fees, the Moot voted him an advance of 40 shillings per member to relieve his necessitous condition. ${ }^{95}$

The members of the Moot recognized a collective responsibility to the courts and cooperated in making their expertise available to the judges. Chief Justice Daniel Horsmanden sought their advice concerning the procedures to be used in examining the attorneys' fees after judgment and later asked them for proposals on the regulation of juries taken from the courtroom to view lands for purposes of valuation. The Moot carefully discussed both questions and certified its answers to the Chief Justice. ${ }^{96}$

It was proposed that a committee from the Moot attend the sittings of the Supreme Court on the first Friday of each quarterly term en banc and prepare for Moot members a list of the questions of law that would be argued during the term. ${ }^{97}$ No record of the appointment of such a committee and no evidence of such cooperative action survive. Presumably this list would have permitted members to attend the arguments on issues in which they were interested. Unfortunately, the step from this activity to recording and publication of arguments and decisions was never taken by the Moot or by anyone else in colonial New York. The American Revolution intervened, breaking up the fellowship of the Moot and ending its activities.

\section{The Quest For A Judgeship}

The scholarly discussions of the Moot and the opinions rendered in New York City courts contrasted sharply with the earthy ad hoc decisions occasionally handed down by the laymen who served in the outlying county courts of justice. Attorneys practicing solely in those courts served relatively short apprenticeships and were badly versed in the English common law. These circumstances led John Jay and his former partner, Robert R. Livingston, Jr., to suggest that legally trained men be appointed to ride circuit among the various courts as advisers to the common pleas judges. When the proposal was originally submitted to the Council by Governor William Tryon in November, 1772, little objection arose. The matter was tabled, however, and attorney William Smith left the Council meeting

\footnotetext{
${ }^{95}$ DuBois Minutes, supra note 90.

${ }^{96}$ Society Minutes, supra note 90 , at 18-19.

${ }^{97}$ Id. 15.
} 
correctly convinced that delay was tantamount to the defeat of the proposal. The prominent political leader Oliver DeLancey realized that political capital could be made of the rural resentment that would greet the proposal. At the next meeting of the Council he characterized the plan as a repudiation of the work of the county magistrates. Again the matter was tabled. According to William Smith, DeLancey partisans sent letters to the counties to arouse local opposition to the proposal. The Livingston political faction rallied against the DeLanceys, but even the suggestion by Jay and Livingston that the advisers serve without compensation failed to obtain a favorable vote in the Council. In the end, Chief Justice Horsmanden agreed with the DeLancey councilors that the arrangement would raise public clamor and was therefore inexpedient. ${ }^{98}$

The proposal next emerged in 1774 in correspondence between Jay and John Vardill, a known loyalist who turned out to be an English spy. Vardill, apparently with the approval of his English superiors, had offered Jay a royal post. Writing in reply, Jay noted his lack of influence with Governor Tryon and suggested that Vardill might better serve Jay by pushing the idea of circuit-riding advisers. In 1784 Vardill used this letter as evidence of his own efforts on behalf of the Crown in proceedings before the Commissioners on Loyalist Claims. There is no evidence that the promise of influence swayed Jay's loyalties or led him to break his pledge to keep secret the deliberations of the First Continental Congress. ${ }^{99}$

Jay obviously desired a post on the bench. He was married in April, 1774, and was completing his sixth year in practice. $\mathrm{He}$ no doubt wished to move on to the ease, perquisites, and emoluments of the colonial Bench. Indeed, with marriage, he had already limited his cases outside New York City. But Jay's political position in the colony did not support his desires. The DeLancey faction, opponents of the Livingstons with whom Jay was linked by former partnership and marriage, ${ }^{100}$ had already frustrated the proposal for court advisers. Nor did Jay have sufficient influence with Tryon, who in 1773 had found Robert

98 William Smith, supra note 35, at 51, 129-30, 132-33.

${ }^{99}$ Letters from John Jay to J. Vardill, May 23, 1774, and Sept. 24, 1774 (AO 13/105/283, 321, Public Record Office, London). See F. Monaghan, supra note 4, at 53-54.

100 Jay's wife was the former Sarah Livingston, daughter of William Livingston. See generally 2 T. Jones, supra note 86 , at 474-75. 
R. Livingston, Jr., the post of recorder for the City of New York. ${ }^{101}$ Even with Vardill's solicitude, Jay was not to find a judicial post within the British Empire.

\section{Law AND SOCIETY IN EighteEnTH-Century New YoRk}

The outbreak of the American Revolution in the province of New York obscures the fundamental changes that had already begun in the law and legal profession of the province.

At first glance, it is true, the New York bar had not changed since the late 1600's. ${ }^{102}$ Admission to the profession continued to be based upon the traditional system of clerkship. Despite the infusion of new practitioners after 1765, the organized Supreme Court bar remained a relatively small and homogeneous group. ${ }^{103}$ The monopolistic tendencies of the colonial advocates surfaced in the 1756 agreement to prohibit clerkships, and even the liberalizations of 1764 and 1767 maintained high barriers to entry into the profession. ${ }^{104}$ Retaining financial and familial connections with the mercantile and landholding interests, the bar at times staunchly defended the status quo. ${ }^{105}$ Initial success at the bar was dependent to a considerable degree on family referrals and the continued interest and patronage of one's mentor. ${ }^{106}$ Access to an administrative office, such as Boundary Commission Clerk ${ }^{107}$ or assistant to county judges, ${ }^{108}$ was governed as much by personal contacts as by ability. In short, the Supreme Court bar in 1771 , as in 1691 , was a relatively small group of professionals closely tied to the powerful landholding and merchant families and dependent upon personal and official favor for advancement.

Yet the old relationships between the bar and society had begun to change. Reliance upon centralized gubernatorial pa-

${ }^{101}$ Minutes of the Court of General Sessions, May 21, 1772-Nov., 1790, at 65, 89 (New York Criminal Court Building, New York City). See also The Burghers of New AMSTERDAM AND The FreEMEN of NEw York, 1675-1866, at 557 (New-York Historical Society Publication Fund No. 18, 1885).

${ }_{102}$ The Supreme Court of Judicature opened its first term on Oct. 6, i691. For a description of its early bar, see 1 P. HAMLIN \& C. BAKER, supra note 82, at 99-110.

${ }^{103}$ See text accompanying note 54 supra.

${ }^{104}$ See text accompanying notes 2-6, 45 supra.

${ }^{105}$ See text accompanying notes 34-43 supra.

${ }^{106}$ See text accompanying notes $57-62,67$ supra.

${ }^{107}$ See text accompanying notes 64-66 supra.

${ }^{108}$ See text accompanying notes 98-101 supra. 
tronage may have begun to decrease in the years after 1760 , with the mercantile community emerging as a more diffuse source of income and power. In order to supplement the modest rewards of practice, the bar traditionally had looked to appointments as surrogates to the Prerogative Court or as clerks in the High Court of Chancery. ${ }^{109}$ We may surmise, however, that the increase in outside sources of income decreased the dependence on gubernatorial favor. Otherwise it would be strange that an established lawyer of Kissam's reputation would have undertaken the defense of William Prendergast, ${ }^{110}$ stranger yet that Jay opposed the governor and attorney-general in the Underwood case. ${ }^{111}$ And it would also be odd that Jay devoted so little effort to obtaining a judicial position. ${ }^{112}$ Indeed, the unusually large number of debt collection cases in the practices of Jay and Kissam demonstrates that the mercantile community was a major source of litigation fees. Jay's comments on patronage posts, made in 1800 , come as no surprise:

Such offices give their Possessors no additional consideration, but on the contrary tend to diminish Confidence in their Professional Merit and Qualifications. The Emoluments of them are not worth the Time they consume, and cannot compensate for the Neglect of professional Studies and Pursuits. An Eminent Counsellor will attract more Respect, and command more influence, as well as money, than almost any office can confer or produce. ${ }^{113}$

Such a sentiment, ringing with pride in the profession and its independence, would have been out of place coming from a colonial lawyer of 1735 .

Armed with this new-found independence, but still possess-

${ }^{109}$ Surrogate appointments, and a struggle over the principal surrogate's office, are discussed in Johnson, supra note 82 , at 99-100, 102-04, 143-44. In the absence of a careful study of chancery procedure in New York, it is impossible to evaluate the patronage value of an appointment as a clerk in the chancery. The minutes of the court and file papers on deposit at the Historical Documents Collection, Queens College, Flushing, N.Y., indicate that all chancery papers were filed with a clerk, usually one of the leading Supreme Court attorneys, who was then entitled to fees for making copies of the originals.

${ }^{110}$ See text accompanying notes $34-43$ supra.

${ }^{111}$ See text accompanying notes 76-77 supra.

112 See text accompanying notes 98-101 supra.

${ }^{113}$ Letter from John Jay to Peter Augustus Jay, Dec. 18, 1800 (Columbia University Libraries, Special Collections). 
ing its traditional connections with the sources of economic power in New York, the bar was not lacking in political power on the eve of the War for Independence.

In many ways the American Revolution was a lawyer's rebellion, for the critical issues concerned imperial constitutional law and the prerogatives of the Crown in the North American colonies. Lawyers were essential to the shaping of the peculiar constitutional rhetoric of the political pamphleteering, and a number of the popular issues were based upon technicalities of the law. The public agitation over appeal by writ of error, rather than by civil law appeal methods, was a problem of procedural law with constitutional overtones. Even when one considers the deft change of emphasis in characterizing Forsey v. Cunningham as an attack upon the institution of common law juries, ${ }^{114}$ it is hard to imagine today how such matters flamed the coals of revolution. The electoral franchise, as defended by Jay in the Underhill case, ${ }^{115}$ would seem to have been far better grist for the revolutionary's mill, and yet it went unheralded in the preRevolutionary history of New York. The Stamp Act, a simple revenue measure, was attacked not as a tax, but rather as an unconstitutional form of taxation by Parliament. ${ }^{116}$ Again, the issue was one that in other times would probably have caused concern only among constitutional lawyers. Legal issues were the sparks that ignited the revolution.

Some New York lawyers may have contributed more than issues to the kindling of Revolution. A few, purportedly following the path of passive resistance, may have actually directed the Stamp Act mobs. ${ }^{117}$ The Sons of Liberty placarded one John Cogshill Knap, ${ }^{118}$ who was a threat to the legal community, suggesting that the profession did indeed help to select the targets of radical wrath. Knap, an English barrister, had been refused

\footnotetext{
114 See text accompanying notes 23-25 supra.

115 See text accompanying notes 76-77 supra.

116 See text accompanying note 26 supra.

117 E. Morgan \& H. Morgan, supra note 26, at 184-85.

The Lawyers levelled at, by the people, to be at the bottom of this disloyal Insurection and seconded by many people of property of the place and its neighbourhood.

/Nov./7th the lawyers deemed by the people here to be Hornets and Firebrands of the Constitution. The Planners and Incendiaries of the present Rupture.
}

The Montresor Journals, supra note 37, at 339. Captain John Montresor, a British Army engineer, held the "rabble" in utter contempt.

${ }^{118}$ The MONTRESOR JOURNALS, supra note 37, at 342. 
admission to the bar by the Supreme Court of Judicature but still attempted to practice law in the colony. ${ }^{119}$ Although he had been harrassed prior to the effective date of the Stamp Act, afterwards the Sons of Liberty suggested that he be hunted "as with hounds." 120

Nevertheless, the New York bar retained a strong element of conservatism, based upon its close affiliations with the landholding and merchant elite of the province. Many of its members viewed the rioting of tenants in the up-river counties with alarm. ${ }^{121}$ The Court of Oyer and Terminer that condemned William Prendergast was composed of many of the lawyers who played a role in the resistance to royal power in New York City, not only in the courtroom but also, perhaps, in the direction of the New York City mob. ${ }^{122}$ The Dutchess County trials resulted in the return of an anti-lawyer vote in the 1768 General Assembly elections. ${ }^{123}$

Like the general population of New York, the lawyers were sharply divided in their allegiances when the Revolution came. Approximately one-half of the men who were in practice with John Jay chose to become leaders in the struggle for independence; the remainder were loyal to the Crown. ${ }^{124}$ Jay's affiliation with the patriot party does not seem to have come from pecuniary motives, ${ }^{125}$ personal friendships, ${ }^{126}$ or private resentments. ${ }^{127}$ Rather, he was convinced by the justice of the patriot cause, and chose to sacrifice his lucrative practice in order to attend the meetings of the Continental Congress as a New York delegate and later to serve in prominent roles in the struggle for independence.

119 The activities of Knap and the public attacks in the press may be followed in New York Gazette and Weekly Post Boy, June 14, July 5, 12, 26, Aug. 2, Sept. 13, 1764, Mar. 7, Apr. 25, 1765.

${ }_{120}$ THE MONTRESOR Journals, supra note 37, at 342.

${ }^{121}$ See notes 34-42 supra \& accompanying text.

${ }^{122}$ John Morin Scott, a member of the court, apparently called for repeal or revolution during the Stamp Act crisis. See C. BECKER, supra note 26, at 59-60.

${ }^{123}$ Id. 59-60; S. LYND, supra note 43, at 51-53; I. MARK, supra note 34, at 158-59.

${ }^{124}$ Colonial Lawyer, supra note 9, at 233-34.

${ }^{125}$ Jay's clientele seems to have been equally divided between loyalists and patriots. Id. 234. This mix of clients suggests that the New York bar had not suffered the polarization that took place in Massachusetts. See Morris, supra note 26, at 205-15.

${ }^{126}$ Benjamin Kissam, Jay's friend and mentor, was among the loyalists. Colonial Lawyer, supra note 9 , at $233-34$.

${ }_{127}$ The frustration of Jay's quest for a judicial post, see text accompanying notes 98-101 supra, does not correlate with his emergence as a patriot. 
Even more profound than the legal profession's impact upon the events leading to the American Revolution was the change in the study and analysis of law, as demonstrated by John Jay's brief legal career. Trained in the traditional clerkship method, Jay had the additional experience of working with the Debating Club and discussing theoretical, philosophical, political, and ethical issues. Furthermore, he associated with young men who were sensitive to the cruelties of the criminal law of the day, and later in life he was to show compassion toward condemned criminals and men and women bound in perpetual servitude. Bred in a generation of lawyers who found their precedents in English statutes and casebooks, Jay amassed a respectable library of those sources and a professional ability directed toward their prompt citation. Yet he also purchased books less useful to New York law and practice-titles on natural law and jurisprudence ${ }^{128}$ - which opened his mind and the minds of his fellows to legal subjects beyond the pronouncements of the courts and parliaments at Westminster.

Most symptomatic of the subtle change in the New York legal profession was the rise of the Moot in 1770 and its survival for four years despite the sharp political controversies that threatened to divide its membership. ${ }^{129}$ In a city teeming with social diversions, congeniality alone could not have preserved the Moot's popularity among the leading lawyers; rather, the challenging intellectual task of debating and resolving the troublesome legal problems of the day drew the attention and enthusiasm of Jay and his friends. As successful practitioners, they had the time to devote to discussion of law in the abstract, divorced from the hurried pressures of practice. The Moot may have been another product of the prosperity of the New York bar, but it is significant that the members of that bar, far from spending their time in nonprofessional pursuits, chose to devote themselves to matters of legal interest.

Had the Moot continued, it might have begun to publish opinions of the Supreme Court of Judicature and records of its own debates, stimulating more complex and current legal analysis. And the Moot may have had a direct impact on legal education. A member, Peter Van Schaack, established law 
classes at Kinderhook, New York, after the Revolution. ${ }^{130}$ Van Schaack's school and the Litchfield Law School of Tapping Reeve $^{131}$ may well be considered the precursors of the academic law schools established in mid-nineteenth century America. The Moot may have been the connecting link between clerkship and pure academic training, the intermediary institution that recognized the need to sharpen the practitioner's legal arts through both analysis and observation. When the method of the Moot was applied to student as well as practitioner, the nature of training and the quality of the bar itself were totally altered.

The broadening views of law and jurisprudence would not have any discernible impact upon legal history until well after the American Revolution, but they undoubtedly had a significant influence upon the men of Jay's generation who were summoned to shape the public and private law of New York State and the United States. Similarly, the compassion felt by Jay and his friends toward the suffering of men in society would only gradually result in amelioration of the penal laws. Jay and his contemporaries were products of an age in transition-legal pro-. fessionals who were fortunate to have been trained by more than the clerkship method alone, but nevertheless men who would never fully appreciate the dynamic and evolutionary qualities of jurisprudence. They built new states and a new nation, but the next generation - that of John Marshall, James Kent and Joseph Story-had to develop the legal framework of their creations.

${ }^{130}$ See H. VAN SchaACK, supra note 14.

131 Hamlin, supra note 2, at 24 n.3. 